\title{
The Determinants of Profitability of Non-bank Financial Institutions in Bangladesh
}

\author{
Md. Farhan Imtiaz ${ }^{1}$, Khaled Mahmud ${ }^{1} \&$ Md. Shahed Faisal ${ }^{1}$ \\ ${ }^{1}$ Institute of Business Administration, University of Dhaka, Bangladesh \\ Correspondence: Khaled Mahmud, Institute of Business Administration, University of Dhaka, Dhaka-1000, \\ Bangladesh. Tel: 88-02-966-1900. E-mail: khaled@iba-du.edu
}

Received: March 15, 2019

Accepted: April 9, 2019

Online Published: April 25, 2019

doi:10.5539/ijef.v11n6p25

URL: https://doi.org/10.5539/ijef.v11n6p25

\begin{abstract}
The non-bank financial institutions (NBFI) industry is considered to be an important source of financing in any economy. Stability of earnings is one of the pre-conditions for survival and growth of any industry in the long run. Keeping the importance of profitability in mind, this paper tries to find out the major financial factors affecting the profitability of the NBFI industry in Bangladesh and evaluate the aspects of the findings. The data was collected for 12 different NBFIs for a period of five years (2013-2017). Return on equity was defined as the dependent variable while firm size, capital adequacy ratio, loan ratio, non-performing loan ratio, deposit ratio, net interest margin, non-interest income margin and cost to income ratio were identified as explanatory or independent variables. Multiple regression analysis was conducted on the data to test the research hypotheses. The findings of the study show that capital adequacy ratio, deposit ratio, non-performing loan ratio and net interest margin were statistically significant at 5\% level. Firm size, loan ratio, net interest margin and non-interest income margin show positive relationship with profitability whereas capital adequacy ratio, deposit ratio, non-performing loan ratio and cost to income ratio show negative relationship with profitability. Non-performing loan ratio and net interest margin were found to have a considerable impact on profitability of NBFIs. This is further supported by the fact that non-performing loans do not generate any income and net interest income is considered the main source of income for a financial institution. The study recommends that the NBFIs in Bangladesh give due attention to these factors to improve their financial performance.
\end{abstract}

Keywords: profitability determinant, non-bank financial institution, financial performance, Bangladesh

\section{Introduction}

\subsection{Rationale of the Study}

The progress of a country depends on the development and growth of all economic entity. The financial system, which is involved in the mobilization of financial resources from the surplus to the deficit sector, is the ultimate force for achieving economic prosperity of a country. With a view to supplement the economic growth and cater to the ever-changing demands of customers, NBFIs have been playing a critical role in the financial sector of Bangladesh by availing additional financial services that are not always been provided by the full-fledged banking industry.

According to Bangladesh Bank, Non-bank Financial Institutions are financial intermediaries that collect funds from the general public and lend the same to cater to the specialized financing needs but are not allowed to accept such deposits payable by check, draft, etc. and operate current accounts.

Under the Financial Institution Act-1993, NBFIs are given license and regulated. They are supervised by Bangladesh Bank following a risk-based supervisory system. The minimum paid-up capital for NBFIs is BDT 1.0 billion as per the Financial Institution Regulation-1994. Industrial Promotion and Development Company (IPDC) was the first NBFI in Bangladesh, which commenced its process in 1981. Since then, the numbers and scope of NBFIs have grown significantly as many state-owned, private, and joint-venture firms have entered the sector. At present, there are 34 NBFIs in Bangladesh among which 3 are Government-owned, 19 are locally private-owned and the rest 12 are joint venture. As on 30 June 2017, the number of branches of NBFIs across the country was 246.

In comparison with commercial banks, the business line of NBFIs is narrow. They are permitted to take term 
deposits for 3 months and above. Their products include term loan, lease finance, bridge finance, revolving finance, syndicated finance, real-estate finance, personal loan, car loan etc. Most NBFIs conduct their merchant banking activities through separate subsidiaries like the banks. Their merchant banking services include issue management, underwriting, portfolio management, corporate advising etc. Some NBFIs provide security brokerage services.

The financial sector of Bangladesh has been facing liquidity crisis in the recent years. Not just the banking industry but also the NBFI industry is affected by it. Some of the players in the industry have been able to remain profitable even though their momentum slowed down. Other players, however, are struggling to stay profitable as the cost of fund has increased significantly because of the crisis. It is one of the biggest challenges towards the sustainability of individual NBFIs as well as the entire industry. This situation demands to investigate whether the profitability of the NBFIs can be enhanced in the following years. Furthermore, NBFIs not only involve themselves in deposit and lending activities but also a wide array of other profit seeking activities as well. Sometimes these activities may lead to very high exposure to risk. Therefore, it is important to find out the factors that contribute most to their profitability. Improving on these factors may lead them to a sustainable future in the long run. This study tries to address the determinants of profitability of non-bank financial institutions in Bangladesh.

\subsection{Literature Review}

Several studies have been conducted to get an insight on the firm-specific profitability determinants of financial institutions. However, most of these studies have been based on commercial banks and very few of them are on non-bank financial institutions. It may be due to the fact that the banking industry is more developed and has a wide spread.

Siddiqui (2012) in her article "Capital Structure Determinants of Non-Bank Financial Institutions (NBFIs) in Bangladesh" tried to form a relation between capital structure decision and several variables including profitability, liquidity, operating leverage, growth rate, firm size etc. The author used long term debt ratios, short term debt ratios and total debt ratios as the measures of the dependent variable i.e. capital structure. The findings showed that, in all the three cases of long-term debt ratio and short-term debt ratio, porfitability ratio was not significant. It also did not comply with the hypothesis that, in case of long term and total debt ratio, profitability has a negative relation. However, the study found profitability to have a negative relation with short term debt complying with the hypothesis although the result was not statistically significant.

Ahmed and Chowdhury (2007) in their article "Non-Bank Financial Institutions in Bangladesh: An Analytical Review" stated that many commercial banks in Bangladesh are engaged in non-bank financial activities within the existing banking framework which has been posing difficulties for the non-bank financial institutions.

Hossain and Shahiduzzaman (2012) in their article "Development of Non-Bank Financial Institutions to Strengthen the Financial System of Bangladesh" stated that the performance of NBFIs in leasing business is an indicator that the industry can be growing up at a sustainable rate and should focus more on activities in the capital market. However, non-banks, having a high cost of fund, are forced to compete with the banks that have a relatively low cost of fund. The authors suggested that this situation somewhat hampers the growth and development of NBFIs.

Farah and Rahman (2012) in their article "Non-Bank Financial Institutions' Profitability Indicators: Evidence from Bangladesh" found that their chosen variables as profitability indicators i.e. operating efficiency, capital structure, fixed charges and income, liquidity condition have impact upon net profit. However, among those variables, liquidity condition and operating efficiency were found to have significant influence on profitability of non-bank sector in Bangladesh.

Asma et al. (2011) in their article "Determinant of Islamic banking institutions' profitability in Malaysia" studied bank-specific factors i.e. size, capital adequacy ratio, liquidity and expenditure management and they found that only size of the firms can statistically influence the profitability of banks.

Samad (2015) in his article "Determinants Bank Profitability: Empirical Evidence from Bangladesh Commercial Banks" claimed that loan deposit ratio, capital risk, credit jeopardy and bank efficiency are influencial factors for determining the profitability of Bangladeshi banks.

Financial Stability Report of Bangladesh Bank (2010) reported increasing ROA and ROE ratios of the then NBFIs from 2006 to 2010 which they claim the consequence of better utilization of assets and equity. Moreover, a decomposition of the sources of total income shows that the dominant contribution is on account of interest income from traditional business, which lends to higher profitability. 
The study on banks' profitability by Sufian and Chong (2008) suggests that the profitability of the Philippines banks depend on all the bank-specific determinant variables and they have statistically significant impact on profitability. During the period under study, the results showed that size, credit risk, and overhead expenses have negative relationship with bank profitability, while non-interest income and capitalization have positive impact. The empirical study also indicates that the rate of inflation is negatively related to Philippines banks' profitability level suggesting that the level of inflation was unanticipated by banks. On the other hand, economic growth, the growth in the money supply, and the level of stock market capitalization has not significantly explained the variations in the profitability of the Philippines banks.

Saklain's (2012) study on commercial banks' profitability in Bangladesh identified that asset size does not have a statistically significant relationship with profitability. It suggests that to achieve a higher level of ROA it is not always necessary to be a larger bank. Net interest margin (NIM) is always considered to be the main source of income of a bank, but in the study, it is found that NIM/assets ratio does not have a significant impact on profitability. But the most significant variable which affects the profitability was found to be the non-interest income/assets ratio. This indicates that greater diversification in banking activities positively influence profitability.

\subsection{Research Hypotheses}

We tested the following research hypotheses that have been formulated based on empirical literature:

$\mathrm{H}_{1}$ : There is a significant relationship between Firm Size and profitability of NBFIs.

$\mathrm{H}_{2}$ : There is a significant relationship between Capital Adequacy Ratio and profitability of NBFIs.

$\mathrm{H}_{3}$ : There is a significant relationship between Loan Ratio and profitability of NBFIs.

$\mathrm{H}_{4}$ : There is a significant relationship between Non-performing Loan Ratio and profitability of NBFIs.

$\mathrm{H}_{5}$ : There is a significant relationship between Deposit Ratio and profitability of NBFIs.

$\mathrm{H}_{6}$ : There is a significant relationship between Net Interest Margin and profitability of NBFIs.

$\mathrm{H}_{7}$ : There is a significant relationship between Non-interest Income Margin and profitability of NBFIs.

$\mathrm{H}_{8}$ : There is a significant relationship between Cost to Income Ratio and profitability of NBFIs.

\section{Methodology}

This study analyzed empirical findings from literature and applied those models on Bangladeshi non-bank financial institutions. The study followed a quantitative approach. In order to understand the panel data, descriptive statistics and correlation matrix were used. Relationships between dependent and independent variables were hypothesized and multiple regression analysis was run on the panel data. The output of multiple regression analysis was then explained to determine the factors affecting profitability of NBFIs in Bangladesh.

\subsection{Data Source}

The study is based on data collected from secondary sources. Data were retrieved mainly from the published annual reports of listed NBFIs in Dhaka Stock Exchange within a 5-years period from 2013 to 2017. At the time of the study, 34 NBFIs were operating in Bangladesh, and among them, 12 NBFIs were selected based on their relative market share and being operational during the analysis period. Other firms were excluded due to non-availability of annual reports at the time of conducting the study.

\subsection{Variables}

A total of nine variables have been chosen for this study. Among them, one was the dependent variable and the other 8 were the explanatory or independent variables.

\subsubsection{Dependent Variable}

In most literatures, bank or NBFI's performance has been measured by Return on Asset (ROA) or Return on Equity (ROE). In this study, Return on Equity (ROE) has been used as the measure of financial institution's profitability. ROE is measure as a firm's net profit divided by its total equity. It indicates a firm's efficiency at generating profit from each unit of shareholders' equity. The formula for ROE is defined as: ROE $=$ Profit after tax / Total shareholders' equity.

\subsubsection{Independent Variables}

We reviewed the relationship between profitability and other firm specific factors for non-bank financial institutions in Bangladesh and identified several independent variables from literature. These independent 
variables were size, capital strength, loan ratio, asset quality, deposit ratio, interest income, non-interest income and operational efficiency. These variables have been briefly described below:

a) Firm Size: It is measured as the natural logarithm of total assets of a firm. A firm may improve its financial performance as it grows bigger. Therefore, firm size is expected to have a positive impact on profitability. However, large firms may sometimes face diseconomies of scale which may cause poor return to the firm.

b) Capital Adequacy Ratio (Capital Strength): It is measured as total equity divided by total assets. This ratio represents the capital strength of a firm. The higher the ratio the lower the need of external financing and thus lower the risk of going bankrupt, which reduces the firm's cost of funds. This ratio is expected to have positive relationship with profitability.

c) Loan Ratio: Loans generate interest income for a financial institution. Loan ratio represents total loans as percentage of total assets. More loans in the asset portfolio are expected to generate more income for a firm and thus a positive relationship is expected between loan ratio and profitability.

d) Non-performing Loan Ratio (Asset Quality): Loans that do not generate interest income for a certain period are classified as non-performing loans (NPL). The amount of NPL in total loan portfolio indicates the quality of loan assets of a financial institution. NPL ratio is measured as total non-performing loans divided by total loans. The higher this ratio the higher the risk of loans becoming bad debt and thus lower the profitability.

e) Deposit ratio: Deposits have the lowest cost of fund for a financial institution. The interest spread is higher for loans that are originated from deposits which enhances the profit margin for the firm. However, if a firm fails to transform its deposits into loans efficiently it may impact profitability negatively. This ratio is measured as total deposits divided by total assets.

f) Net Interest Margin: It is measured as net interest income divided by total assets. It is one of the most important indicators of performance of a financial institution because these firms depend highly on interest generating activities. It is expected to show positive relationship with profitability.

g) Non-interest Income Margin: Non-interest income of a financial institution is generated from non-traditional financial activities such as commissions, fees, investment income from government or private securities, and other operating incomes. It is measured as total non-interest income divided by total assets. It is expected to impact profitability positively.

h) Cost to Income Ratio (Operational Efficiency): It shows a company's costs in relation to its income. It is measured by dividing a firm's operating costs by operating income. It shows how efficiently a firm is running. The lower the ratio, the more profitable the firm will be.

\subsection{Model Specification}

The regression model to test our hypotheses based on the variables we have chosen is given below:

$$
R O E=\beta_{0}+\beta_{1} F S+\beta_{2} C A R+\beta_{3} L R+\beta_{4} N P L R+\beta_{5} D R+\beta_{6} N I M+\beta_{7} N I I M+\beta_{8} C I R+\varepsilon
$$

Where, ROE = Return on Equity; FS = Firm size; CAR = Capital Adequacy Ratio; LR = Loan Ratio; NPLR = Non-performing Loan Ratio; DR $=$ Deposit Ratio; NIM $=$ Net Interest Margin; NIIM $=$ Non-interest Income Margin; CIR $=$ Cost to Income Ratio; $\beta 0,1,2, \ldots, 8=$ Coefficients to be estimated; and $\varepsilon=$ Error component for the firm.

\section{Result and Analysis}

\subsection{Descriptive Statistics}

Table 1. Descriptive statistics

\begin{tabular}{lccccc}
\hline Variable & Observation & Mean & Std. Deviation & Minimum & Maximum \\
\hline ROE & 60 & $13.74 \%$ & $8.17 \%$ & $1.19 \%$ & $44.59 \%$ \\
FS & 60 & 9.91 & 0.84 & 8.35 & 11.44 \\
CAR & 60 & $16.43 \%$ & $8.23 \%$ & $7.50 \%$ & $43.73 \%$ \\
LR & 60 & $73.85 \%$ & $8.11 \%$ & $54.85 \%$ & $87.73 \%$ \\
NPLR & 60 & $4.75 \%$ & $2.68 \%$ & $0.22 \%$ & $10.91 \%$ \\
DR & 60 & $50.97 \%$ & $19.25 \%$ & $0.00 \%$ & $76.09 \%$ \\
NIM & 60 & $3.72 \%$ & $1.29 \%$ & $1.23 \%$ & $6.72 \%$ \\
NIIM & 60 & $0.92 \%$ & $0.53 \%$ & $0.03 \%$ & $2.54 \%$ \\
CIR & 60 & $27.87 \%$ & $12.84 \%$ & $4.78 \%$ & $52.48 \%$ \\
\hline
\end{tabular}


The above table shows mean, standard deviation, minimum and maximum values for each variable. From the table we can see that, on an average, the NBFIs have a return on equity of $13.74 \%$. The ROE varies significantly with a standard deviation of $8.17 \%$. While all the firms achieved positive return during our observed time period, the ROE has a wide dispersion from $1.19 \%$ to $44.59 \%$.

Size of the firms has been determined by the natural logarithm of total assets, the mean of which is 9.91 and standard deviation is 0.84. It suggests that our data includes firms of different sizes. The firms have an average capital adequacy ratio of $16.43 \%$ which goes as high as $43.73 \%$.

Loan ratio and NPL ratio show that, on an average, $73.85 \%$ of NBFIs' total assets are loans; while, on an average, $4.75 \%$ of the total loans are non-performing. The minimum and maximum NPL ratios are $0.22 \%$ and $10.91 \%$ which suggest that the asset quality of NBFIs varies significantly.

Even though NBFIs can only collect term deposits of three months and above, the average deposit ratio is $50.97 \%$. One of the firms in our study does not have any deposit financing. As a result, the minimum value of deposit ratio is $0 \%$ while the maximum value is $76.09 \%$.

Average net interest margin is $3.72 \%$ while average non-interest income margin is $0.92 \%$. Lower non-interest income margin compared to net interest margin indicates that NBFIs do not generate much income from non-traditional financial activities.

Average cost to income ratio is $27.87 \%$. The minimum and maximum values are $4.78 \%$ and $52.48 \%$ which imply that some firms are very efficient in their operation while other firms incur more than $50 \mathrm{Tk}$ operating expense to generate every 100 Tk operating income.

\subsection{Correlation Matrix}

Table 2. Correlation matrix

\begin{tabular}{|c|c|c|c|c|c|c|c|c|c|}
\hline Variable & ROE & FS & CAR & LR & NPLR & DR & NIM & NIIM & CIR \\
\hline ROE & 1 & & & & & & & & \\
\hline FS & 0.48 & 1 & & & & & & & \\
\hline CAR & -0.50 & -0.78 & 1 & & & & & & \\
\hline LR & 0.00 & -0.06 & -0.08 & 1 & & & & & \\
\hline NPLR & -0.53 & -0.41 & 0.42 & -0.24 & 1 & & & & \\
\hline DR & -0.12 & -0.05 & -0.17 & 0.67 & -0.40 & 1 & & & \\
\hline NIM & 0.46 & -0.11 & 0.07 & 0.19 & -0.11 & -0.05 & 1 & & \\
\hline NIIM & -0.26 & -0.25 & 0.51 & 0.09 & 0.10 & 0.02 & -0.09 & 1 & \\
\hline CIR & -0.13 & 0.09 & -0.16 & 0.31 & -0.27 & 0.63 & -0.25 & 0.33 & 1 \\
\hline
\end{tabular}

The correlation matrix shows that, there are some positive and some negative correlations between independent variables. Firm size, capital adequacy ratio and NPL ratio are negatively related to loan ratio whereas deposit ratio, net interest margin, non-interest income margin and cost to income ratio are positively correlated. Firm size has inverse relationship with all the independent variables except for cost to income ratio. NPL ratio is negatively correlated with all the independent variables except for capital adequacy ratio and non-interest income margin. Net interest margin has positive correlation with capital adequacy ratio and loan ratio. The degree of correlation among the variables has been observed in order to check if there is any multicollinearity problem. The table shows that the correlation is not higher than 0.8 between any two independent variables. We can primarily conclude that our model does not have multicollinearity problem.

The matrix also shows that firm size and net interest margin are positively related to ROE whereas capital adequacy ratio, NPL ratio, deposit ratio, non-interest income margin and cost to income ratio are negatively correlated. Loan ratio apparently shows no correlation with ROE. The degree of correlation suggests that non-performing loan ratio has the strongest correlation with ROE whereas deposit ratio has the weakest correlation. 


\subsection{Multiple Regression}

Table 3. Multiple regression

\begin{tabular}{|c|c|c|c|c|c|}
\hline Regression Output & & & & & \\
\hline Multiple R & 0.825 & & & & \\
\hline R Square & 0.681 & & & & \\
\hline Adjusted R Square & 0.631 & & & & \\
\hline Standard Error & 0.050 & & & & \\
\hline \multirow[t]{2}{*}{ Observations } & 60 & & & & \\
\hline & df & SS & MS & $\mathrm{F}$ & Significance $\mathrm{F}$ \\
\hline Regression & 8 & 0.268 & 0.034 & 13.633 & 0.000 \\
\hline Residual & 51 & 0.126 & 0.002 & & \\
\hline \multirow[t]{2}{*}{ Total } & 59 & 0.394 & & & \\
\hline & Coefficients & Standard Error & $\mathrm{t}$ Stat & P-value & \\
\hline Intercept & 0.223 & 0.188 & 1.188 & 0.240 & \\
\hline FS & 0.001 & 0.014 & 0.060 & 0.952 & \\
\hline CAR & -0.413 & 0.163 & -2.524 & 0.015 & \\
\hline LR & 0.024 & 0.117 & 0.209 & 0.835 & \\
\hline NPLR & -1.395 & 0.307 & -4.540 & 0.000 & \\
\hline DR & -0.159 & 0.065 & -2.430 & 0.019 & \\
\hline NIM & 2.632 & 0.558 & 4.718 & 0.000 & \\
\hline NIIM & 0.612 & 1.770 & 0.346 & 0.731 & \\
\hline CIR & -0.002 & 0.080 & -0.022 & 0.983 & \\
\hline
\end{tabular}

Regression output shows that, the $\mathrm{R}^{2}$ value is 0.681 which suggests that the independent variables in our model can explain $68.1 \%$ variation in ROE. The adjusted $\mathrm{R}^{2}$ is 0.631 which is also reliable. The F statistics is very significant at $5 \%$ level which suggests that there is significant relationship between the dependent variable and at least one independent variable. So, we proceed with our model and test our hypotheses for each independent variable.

\subsection{Hypothesis Test}

Firm Size: Firm size is positively related to ROE. However, the coefficient value suggests that the impact of firm size on ROE is negligible. We also see that, firm size is statistically insignificant at 5\% level. Therefore, we cannot conclude that there is significant relationship between firm size and profitability of Bangladeshi NBFIs.

Capital Adequacy Ratio: Capital adequacy ratio shows an inverse relationship with ROE. It could be due to the fact that, if equity capital increases then the denominator in ROE increases which ultimately reduces the measurement of ROE. We also see that, this variable is statistically significant at $5 \%$ level.

Loan Ratio: Loan ratio has a positive impact on ROE. However, it is statistically insignificant at 5\% level. Therefore, we cannot conclude that there is significant relationship between loan ratio and profitability of NBFIs.

Non-performing Loan Ratio: NPL ratio is negatively related to ROE. The coefficient value suggests that $1 \%$ decrease in NPL ratio will result in 1.4\% increase in ROE. It is also statistically significant at $5 \%$ level. Higher NPL ratio indicates lower interest income and poorer asset quality. Reducing non-performing loans can be an effective way to increase profitability of financial institutions.

Deposit Ratio: Deposit ratio has a negative relationship with ROE. It is also statistically significant at $5 \%$ level. It suggests that NBFIs in Bangladesh are not efficiently transforming deposits into loans which is affecting their profitability negatively. The coefficient value indicates that, $1 \%$ increase in deposit ratio will result in $0.16 \%$ decrease in ROE.

Net Interest Margin: Net interest margin is positively related to ROE. The coefficient value is also highest among all the independent variables. It is statistically significant at $5 \%$ level. Keeping other things constant, $1 \%$ increase in net interest margin will result in $2.63 \%$ increase in ROE.

Non-interest Income Margin: Non-interest income margin has a positive relationship with ROE which implies that earnings from non-traditional financial activities enhance ROE. However, it is statistically insignificant at 5\% level. Therefore, we cannot conclude that there is significant relationship between non-interest income and 
profitability of NBFIs.

Cost to Income Ratio: Cost to income ratio has inverse relationship with ROE which implies that higher operational efficiency results in higher profitability. However, this variable is statistically insignificant at 5\% level. Therefore, we cannot conclude that there is significant relationship between operational efficiency and profitability of NBFIs.

\section{Conclusion}

This study investigates the factors affecting the financial performance of non-bank financial institutions in Bangladesh. There are currently 34 NBFIs operating in the country. Along with the rising number of commercial banks, the competition is quite intense in the NBFI industry and intense competition can drive the average profitability of the industry down. In our analysis, we have identified eight factors that may affect the profitability of the NBFIs. We have found that, not all of them show significant relationship with profitability. Among the independent variables, capital adequacy ratio, deposit ratio, non-performing loan ratio and net interest margin expressively influence the profitability of NBFIs in Bangladesh. The first three variables affect profitability negatively while the last one affects it positively.

The inverse relationship between capital adequacy ratio and return on equity implies that, if increase in equity capital fails to increase net profit at the same rate the higher equity value will drive ROE down. Therefore, NBFIs need to convert their equity capital into profit generating assets otherwise it will pose negative impact on their profitability. The same goes for deposit ratio. Deposits need to be efficiently converted into loans. Otherwise, increasing deposit will hamper profitability because idle deposit does not generate any income, but it incurs interest expense.

The rise of non-performing loans (NPL) is one the major concerns for the financial sector in Bangladesh. If NBFIs can decrease their individual rate of NPL, our analysis shows that, their profitability will be increased significantly. There are three main causes behind the rise of NPL: weakness in project analysis, lack of skilled manpower, and monitoring. Project analysis is of the essence in granting loans, but financial institutions still give priority to mortgaged property instead of looking at project viability. The loan recovery from mortgaged property is very insignificant, so financial institutions should give loans analyzing project viability. If the project becomes viable and have adequate cash flow, the loan will be out of default risk, even if there is no adequate collateral. Also, keeping down NPL will improve the overall net interest margin which, our study shows, will enhance ROE significantly. We hope that government, institutions, investors and policymakers will find the findings of this study useful. While investors can use these factors to identify which firms to invest in, firms can consider these factors to enhance their profitability. These factors will also help regulators monitor and assess the chance of bankruptcy by these NBFIs.

\section{References}

Ahmed, M., \& Chowdhury, M. (2007). Non-Bank Financial Institutions in Bangladesh: An Analytical Review. (Working Paper Series: WP 0709). Bangladesh: Bangladesh Bank.

Asma'Rashidah Idris, F. F. A., Asari, H., Taufik, N. A. A., Salim, N. J., Mustaffa, R., \& Jusoff, K. (2011). Determinant of Islamic banking institutions' profitability in Malaysia. World Applied Science Journal, 12, 01-07.

Bangladesh Bank. (2016). Financial Stability Report.

Gremi, E., \& Ballkoci, V. (2016). The Determinants of Non Banking Financial Institutions Profitability. Research Journal of Finance and Accounting, 7(20).

Hossain, M., \& Shahiduzzaman, M. (2012). Development of Non Bank Financial Institutions to Strengthen the Financial System of Bangladesh. Quarterly Journal of Bangladesh Institute of Bank Management, 28(1).

Khandoker, M., \& Raul, R. (2013). Determinants of profitability of Non Bank Financial Institutions' in a developing country: Evidence from Bangladesh. International Journal of Management Sciences and Business Research, 2(4).

Lalon, R. M., \& Hussain, S. (2017). An Analysis of Financial Performance on Non-bank Financial Institutions (NBFI) in Bangladesh: A Study on Lanka-Bangla Finance Limited. International Journal of Economics, Finance and Management Sciences, 5(5), 251. https://doi.org/10.11648/j.jefm.20170505.14

Mazumder, M. (2015). Stimulants of Profitability of Non-Bank Financial Institutions: Evidence from Bangladesh. International Journal of Business and Management Review, 3(10). 
Rahman, S., \& Farah, T. (2012). Non Bank Financial Institutions' Profitability Indicators: Evidence from Bangladesh. International Journal of Applied Research in Business Administration and Economics, 1 (1).

Rifat, A. M. (2017). An Analytical Study of Determinants of Non-Performing Loans: Evidence from Non-Bank Financial Institutions (NBFIs) of Bangladesh. Journal of Business and Technology (Dhaka), 55-67. https://doi.org/10.3329/jbt.v11i1.34242

Saklain, M. (2012). The Profitability Determinants of Private Commercial Banks in Bangladesh. Asian Institute of Technology (School of Management). Retrieved from http://www.pmbf.ait.ac.th/sites/default/files/report/report_sohelsaklain.pdf

Samad, A. (2015). Determinants Bank Profitability: Empirical Evidence from Bangladesh Commercial Banks. International Journal of Financial Research, 6(3). https://doi.org/10.5430/ijfr.v6n3p173

Siddiqui, S. (2012). Capital structure determinants of Non-Bank Financial Institutions (NBFIs) in Bangladesh. World Review of Business Research, 2(1), 60-78.

Sufian, F., \& Chong, R. R. (2008). Determinants of bank profitability in a developing economy: Empirical evidence from the Philippines. Asian Academy of Management Journal of Accounting \& Finance, 4(2).

\section{Copyrights}

Copyright for this article is retained by the author(s), with first publication rights granted to the journal.

This is an open-access article distributed under the terms and conditions of the Creative Commons Attribution license (http://creativecommons.org/licenses/by/4.0/). 